\title{
Correction to: Health care services use among long-term breast cancer survivors: a systematic review
}

\author{
Anna Jansana ${ }^{1,2,3}$ - Margarita Posso ${ }^{1,3}$ - Inmaculada Guerrero ${ }^{4}$ Alexandra Prados-Torres ${ }^{3,4}$. \\ Maria Isabel Del Cura ${ }^{3,5,6}$. Xavier Castells ${ }^{1,3,7}$. Maria Sala ${ }^{1,3,7}$ (iD
}

Published online: 27 May 2019

(C) Springer Science+Business Media, LLC, part of Springer Nature 2019

\section{Correction to: Journal of Cancer Survivorship https://doi.org/10.1007//11764-019-00755-z}

The article Health care services use among long-term breast cancer survivors: a systematic review, written by Anna Jansana, Margarita Posso, Inmaculada Guerrero, Alexandra Prados-Torres, Maria Isabel Del Cura, Xavier Castells and Maria Sala, was originally published electronically on the publisher's internet portal (currently SpringerLink) on 09 April 2019 with open access. With the author(s)' decision to step back from Open Choice, the copyright of the article changed on May 2019 to (C) Springer Science+Business Media, LLC, part of Springer Nature 2019 and the article is forthwith distributed under the terms of copyright.

The Original article has been corrected.

Publisher's note Springer Nature remains neutral with regard to jurisdictional claims in published maps and institutional affiliations.

The online version of the original article can be found at https://doi.org/ 10.1007/s11764-019-00755-Z

Maria Sala

msalaserra@parcdesalutmar.cat

1 Department of Epidemiology and Evaluation, IMIM (Hospital del Mar Medical Research Institute), Passeig Marítim, 25-29, 08003 Barcelona, Spain

2 European Higher Education Area (EHEA) Doctoral Programme in Methodology of Biomedical Research and Public Health in Department of Pediatrics, Obstetrics and Gynecology, Preventive Medicine and Public Health, Universitat Autónoma de Barcelona (UAB), Bellaterra, Barcelona, Spain

3 Research Network on Health Services in Chronic Diseases (REDISSEC), Barcelona, Spain
4 Grupo EpiChron de Investigación en Enfermedades Crónicas, IACS, IIS Aragon, Unidad Docente de Medicina Preventiva y Salud Pública, Hospital Universitario Miguel Servet, Paseo Isabel La Católica 1-3, 50009 Zaragoza, Spain

5 Primary Care Research Unit, Gerencia de Atención Primaria, Madrid, Spain

6 Department of Preventive Medicine and Public Health, University Rey Juan Carlos, Avenida de Atenas, 28922 Alcorcón, Madrid, Spain

7 Autonomous University of Barcelona (UAB), 08193 Bellaterra, Barcelona, Spain 